\title{
Vitamin E Does Not Prevent Oxygen-Induced Lung Injury in Newborn Lambs
}

\author{
THOMAS N. HANSEN, THOMAS A. HAZINSKI, AND RICHARD D. BLAND ${ }^{(36)}$ \\ Cardiovascular Research Institute and Department of Pediatrics, University of California, San Francisco, California; \\ Department of Pediatrics, Baylor College of Medicine, Houston, Texas; and Department of Pediatrics, Northwestern \\ University School of Medicine, Chicago, Illinois USA
}

\section{Summary}

In newborn lambs, lung vascular permeability to protein increases after 3 days of continuous oxygen breathing. We studied six unanesthetized lambs that were less than 1 month old to see if intramuscular administration of vitamin $\mathbf{E}$, an antioxidant, would prevent or lessen the severity of this oxygen-induced lung injury. To assess lung fluid balance, we measured pulmonary arterial and left atrial pressures, lung lymph flow, and concentrations of protein in lymph and plasma of lambs that received intramuscularly vitamin E, $20 \mathrm{mg} / \mathrm{kg}$ body weight, for 2 days before the experiment and then daily as they breathed pure oxygen. Despite a 10-fold increase in the plasma concentration of vitamin $\mathrm{E}(2.5 \pm 0.4 \mu \mathrm{g} /$ $\mathrm{ml}$ to $24.4 \pm 2.9 \mu \mathrm{g} / \mathrm{ml}$ ), pulmonary microvascular permeability to protein increased in all of the lambs within 3 days of sustained hyperoxia: lung lymph flow tripled, the concentration of protein in lymph increased, and the ratio of the albumin concentration to the globulin concentration in lymph, relative to that in plasma, decreased. Vascular pressures did not change significantly during the course of oxygen breathing. In four lambs, we injected $\left[{ }^{125} I\right]-$ albumin into the right atrium and determined the time for specific activity in lymph to reach one-half that of plasma (half-equilibration). The time averaged $146 \pm 21 \mathrm{~min}$ before oxygen breathing and $46 \pm 7 \mathrm{~min}$ after 3 days in oxygen. These data provide clearcut evidence that severe endothelial injury occurred. All six lambs died of respiratory failure after 4 days or less in oxygen. Extravascular lung water per $g$ of dry lung tissue was significantly greater in these lambs than in control lambs $(5.88 \pm 0.46$ versus $4.72 \pm 0.14)$.

These results show that sustained hyperoxia increased transvascular movement of fluid and protein into the pulmonary interstitium and caused edema. The outcome of these studies was almost identical to that of previous experiments in which lambs continuously breathed oxygen but did not receive vitamin $E$. We conclude that vitamin $E$ was not effective in protecting the lungs from microvascular injury.

\section{Speculation}

These results suggest that administration of vitamin $E$ to animals that are not deficient in vitamin $E$ does not protect them from oxygen-induced lung injury.

When newborn lambs breathe pure oxygen continuously for 3-5 days, protein-rich fluid leaks from lung blood vessels into the interstitial tissue and pulmonary edema develops (4). The vascular injury appears to be mediated by release of toxic oxygen radicals that damage structural proteins and cause peroxidation of lipid membranes in the lung $(5,6,8,9,15,17,19,29)$. Vitamin $\mathrm{E}(\alpha-$ tocopherol) is a biologic antioxidant that inhibits lipid peroxidation $(2,3,10,20,21,28)$. Previous studies have demonstrated that oxygen is particularly toxic to the lungs of animals that are deficient in vitamin $\mathrm{E}$, and that administration of vitamin $\mathrm{E}$ to such animals may be beneficial $(24,30,31,33)$. We therefore designed a set of experiments to see if supplemental vitamin $\mathrm{E}$ might protect the lungs of newborn lambs from oxygen toxicity.

We measured pulmonary arterial and left atrial pressures, lung lymph flow and the concentration of protein in lymph and plasma of six newborn lambs that received intramuscularly vitamin $\mathrm{E}, 20$ $\mathrm{mg} / \mathrm{kg}$, for 2 days before the experiment and then daily as they breathed pure oxygen. We found that vitamin E did not prevent or lessen the toxic effects of oxygen on the pulmonary endothelium of these lambs.

\section{MATERIALS AND METHODS}

Surgical preparation. Previous papers $(1,27)$ describe in detail how we surgically prepared the lambs for experiments. Briefly, we operated on each of six lambs twice, first when they were less than 2 days old, and again 7-10 days later. For both procedures we anesthetized the lambs with halothane and nitrous oxide and used a piston-type respirator (Model 607, Harvard Apparatus Co., Inc., Millis, MA, USA) for mechanical ventilation. Before and after surgery we kept the lambs with their mothers for feeding and warmth.

During the first operation, we inserted polyvinyl catheters into the left carotid artery and jugular vein through an incision in the neck and advanced the catheters until their tips were in the thoracic aorta and right atrium respectively. Through a left thoracotomy we placed polyvinyl catheters directly into the left atrium and main pulmonary artery.

In the second operation, a right thoracotomy, we resected the systemic contributions to the caudal mediastinal lymph node and inserted a polyvinyl catheter, impregnated with heparin (TDMAC Processing, Polyscience, Inc., Warrington, PA, USA), into the efferent duct of that node. In addition, we placed a $3 \times 3 \mathrm{~cm}$ silicone balloon (Silastic, Dow Corning Corp., Midland, MI, USA) in the pleural space for subsequent measurement of pleural pressure. We allowed the lambs at least 3 days to recover from surgery before starting experiments.

Experimental procedure. The average weight of the lambs was $8.4 \pm 0.7 \mathrm{~kg}$. Their average age when experiments began was 26 \pm 2 days. We gave the lambs vitamin E (DL- $\alpha$-tocopherol, Roche Pharmaceuticals, Nutley, NY, USA), $20 \mathrm{mg} / \mathrm{kg}$ body weight, as a single intramuscular injection for 2 days before the experiments began and daily thereafter. Two days after the first injection, we took the lambs from their mothers and placed them in a sealed wood and lucite box into which oxygen flowed at 6-8 liter/min, a rate sufficient to keep the partial pressure of oxygen in the inspired gas greater than 700 torr. We used buckets of ice and soda lime to keep the temperature inside the box $24-26^{\circ} \mathrm{C}$ and to keep the partial pressure of carbon dioxide less than 4 torr. While the lambs were in oxygen, we fed them commercial infant formula (Similac, Ross Laboratories, Columbus, $\mathrm{OH}, \mathrm{USA}$ ) that provided them with $150 \mathrm{ml} / \mathrm{kg}$ and $100 \mathrm{cal} / \mathrm{kg}$ daily. Two control lambs received vitamin $E, 20 \mathrm{mg} / \mathrm{kg}$ daily for 5 days, as they breathed air without supplemental oxygen. 
At the beginning of the experiments and at 24-h intervals thereafter, we measured vascular and pleural pressures, heart rate, respiratory rate, cardiac output, arterial $\mathrm{pH}$, and partial pressures of oxygen $\left(\mathrm{PaO}_{2}\right)$ and carbon dioxide $\left(\mathrm{PaCO}_{2}\right)$ in arterial blood. We collected samples of lung lymph every $30 \mathrm{~min}$ and measured their volume to the nearest $0.01 \mathrm{ml}$. We obtained samples of aortic blood at hourly intervals. We studied the lambs daily during a 3-4 h steady-state period, as they breathed $100 \%$ oxygen. We measured pulmonary arterial, left atrial, and aortic pressures with Statham P23Db strain gauge manometers (Statham Instruments, Hato Rey, Puerto Rico), and pleural pressure with a Statham PM131TC differential pressure transducer. The zero reference for vascular pressures was the level of the left atrium; for measurement of pleural pressure, zero reference was atmospheric pressure. We recorded pressure tracings on a Grass 7D 8-channel amplifier recorder (Grass Instruments, Quincy, MA, USA). Heart rate and respiratory rate were obtained from phasic recordings of aortic and pleural pressures. Cardiac output was determined by the indicator dilution method (25) with Cardio-green dye (Hynson, Wescott, and Dunning, Inc., Baltimore, MD, USA). We calculated pulmonary vascular resistance as the difference between pulmonary arterial and left atrial pressures, divided by the cardiac output. Arterial $\mathrm{pH}$, and partial pressures of oxygen and carbon dioxide in arterial blood and inspired gas were measured with a Corning blood gas analyzer (Corning Glass Works, Medfield, MA, USA).

Protein tracer studies. We determined the rate of transfer of radioiodinated albumin from plasma into lung lymph in four of the lambs just before they began breathing oxygen and again 3 days later. For these studies, we obtained two baseline samples of blood and lymph, after which we injected into the right atrium 2-3 $\mu \mathrm{Ci} / \mathrm{kg}$ of $\left.{ }^{125} \mathrm{I}\right]$-human albumin (Mallinkrodt, Inc., St. Louis, MO, USA). We then collected samples of lymph every $30 \mathrm{~min}$ for 2-3 $\mathrm{h}$ and samples of aortic blood at the midpoint of each lymph collection period.

Analytic methods. We centrifuged samples of blood and lymph and measured concentrations of protein in the supernatant fluids with a refractometer (American Optical Corp., Buffalo, NY, USA). We confirmed these concentrations by the biuret method (16) and then measured protein fractions by cellulose acetate electrophoresis (Microzone 110, Beckman Instruments, Inc., Fullerton, CA, USA). In addition, we measured total tocopherol concentration in pooled daily samples of plasma and lymph (18).

For the protein tracer studies we transferred $0.1 \mathrm{ml}$ of each sample of lymph and plasma into test tubes and measured the radioactivity in each for $1 \mathrm{~min}$ in a Searle 512 multichannel pulseheight analyzer (Searle Analytic, Inc., Des Plaines, IL, USA). To calculate the specific activity for each sample of fluid, we divided the number of counts per min by the concentration of albumin in the fluid. Then we plotted the ratio of lymph specific activity to plasma specific activity as a function of time, drew a regression line through the points, and from that plot determined the time required for the specific activity in lymph to reach one-half that of plasma $\left(\mathrm{T}_{1 / 2}\right)$.

Postmortem studies. When respiratory failure occurred in the lambs, we anesthetized them with sodium pentobarbital, $20 \mathrm{mg} /$ $\mathrm{kg}$ intravenously, and resected their lungs at an inflation pressure of $25 \mathrm{~cm} \mathrm{H}_{2} \mathrm{O}$. We rapidly froze a small portion of lung by immersing it in liquid nitrogen for subsequent examination under a microscope. We homogenized the remaining lung to measure extravascular water content by a modification (13) of the method of Pearce et al. (23). For each lamb we calculated dry lung weight, exclusive of blood, so that we could express pulmonary lymph flow and protein clearance relative to lung tissue weight.

Statistical analysis. We used a paired $t$ test (26) to compare measurements made during the first $4 \mathrm{~h}$ of oxygen breathing with measurements obtained on the third day in oxygen. We originally intended to compare results obtained at the start of oxygen breathing with results obtained after the lambs had been in oxygen for 5 days, but this was not possible because two of the lambs died from oxygen toxicity within 3 days. We expressed all data in the text and tables as the mean \pm 1 S.E. from the mean and accepted as significant those differences that were supported by a $P$ value $<0.05$.

\section{RESULTS}

General. Administration of vitamin $\mathrm{E}$ increased the plasma concentration of tocopherol from $2.5 \pm 0.4 \mu \mathrm{g} / \mathrm{ml}$ to $24.4 \pm 2.9$ $\mu \mathrm{g} / \mathrm{ml}$ and the lymph concentration from $1.1 \pm 0.2 \mu \mathrm{g} / \mathrm{ml}$ to 4.7 $\pm 0.5 \mu \mathrm{g} / \mathrm{ml}$. There was no appreciable change in these concentrations for the duration of oxygen breathing. Vitamin $\mathrm{E}$ had no effect on vascular pressures or lung lymph flow during the 2 days before the lambs received oxygen, nor was any effect observed in the 2 control lambs that were treated for 5 days as they breathed air. Body weight and temperature did not change significantly during experiments.

Effects of oxygen breathing in lambs given vitamin $E$. After 48-96 $\mathrm{h}$ in oxygen, the lambs became lethargic and weak, with retractions of the chest wall during inspiration. All of the lambs died of respiratory failure: four after $96 \mathrm{~h}$, one after $72 \mathrm{~h}$, and one after 50 $\mathrm{h}$ in oxygen. During the last study period before death, the $\mathrm{pH}$ of the lambs averaged $7.08 \pm 0.07$, their $\mathrm{PaO}_{2}$ was $178 \pm 71$ torr, and their $\mathrm{PaCO}_{2}$ was $112 \pm 17$ torr.

Figure 1 shows results from one experiment in which a lamb breathed oxygen for 4 days. Lymph flow decreased initially, but by the third day in oxygen, there was a 3-fold increase in lymph flow. Lymph protein concentration increased progressively throughout the experiment; vascular pressures did not change.

Table 1 is a summary of respiratory and circulatory data for the six experiments. The lambs breathed more slowly in oxygen than they did in air, and the $\mathrm{PaCO}_{2}$ progressively increased. Aortic blood pressure, heart rate, cardiac output, and pulmonary vascular resistance did not change.

Table 2 is a summary of data related to lung fluid balance. Pulmonary arterial and left atrial pressures did not change significantly during oxygen breathing. Lung lymph flow tripled, the concentration of protein in lymph increased, and the ratio of the albumin concentration to the globulin concentration in lymph relative to that in plasma decreased in all of the lambs after 3 days in oxygen.

Radioactive tracer studies. Figure 2 shows the results of one radioactive tracer study. After injection of $\left[{ }^{125} \mathrm{I}\right]$-albumin, the specific activity of albumin in lymph relative to that in plasma increased linearly as a function of time. In four such studies, $T_{1 / 2}$ decreased from $146 \pm 21 \mathrm{~min}$ during air breathing to $46 \pm 7 \mathrm{~min}$ after $72 \mathrm{~h}$ of oxygen breathing. This change in equilibration time was the result of a more rapid increase in the specific activity of

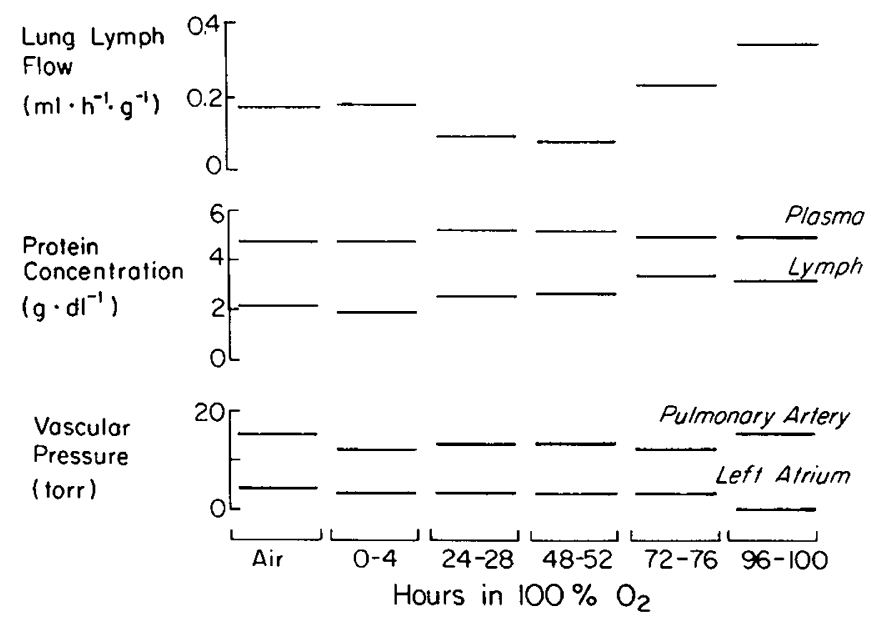

Fig. 1. Lung lymph flow (per $\mathrm{g}$ of dry lung tissue, excluding blood), protein concentrations, and mean vascular pressures in a lamb breathing air and then $100 \%$ oxygen for 4 days. 


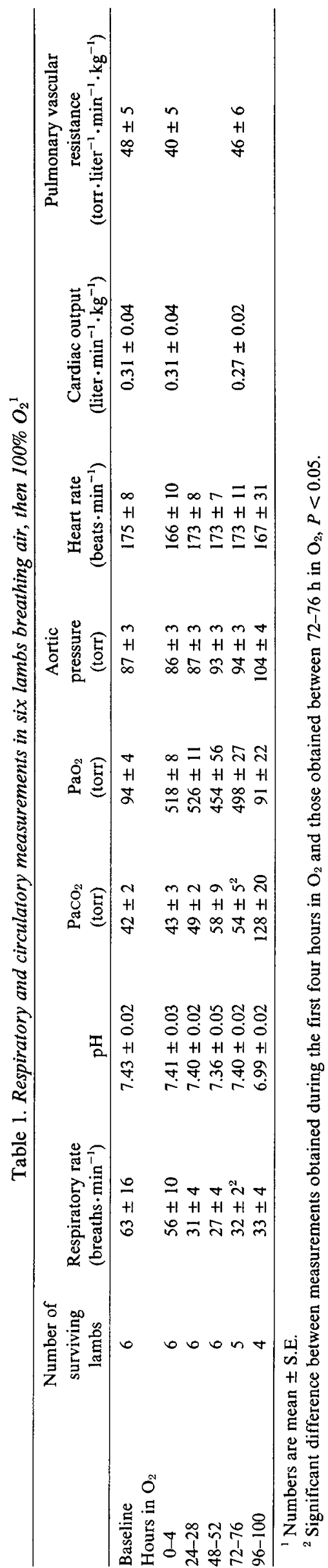

albumin in lymph. Oxygen breathing had no effect on the rate of decrease of the specific activity in plasma.

Postmortem studies. Extravascular lung water per $\mathrm{g}$ of dry lung tissue, exclusive of blood, was significantly greater $(5.88 \pm 0.46)$ than it was in control lambs $(4.72 \pm 0.14)(1)$. Photomicrographs of frozen sections of lung showed extensive cuffs of fluid surrounding blood vessels, and in some cases there was fluid within the air spaces.

\section{DISCUSSION}

DeLemos and coworkers (7) showed that pulmonary edema develops in newborn lambs when they breathe pure oxygen for 3-4 days. Bressack and associates (4) demonstrated that this oxygen-induced lung injury is the result of increased permeability to protein in the pulmonary microcirculation. The purpose of this work was to see if vitamin $\mathrm{E}$, an antioxidant, might prevent lung endothelial injury in lambs breathing pure oxygen. Despite a 10fold increase in plasma concentrations and a 5-fold increase in lymph concentrations of tocopherol, lymph flow tripled and the concentration of protein in lymph increased in all the lambs after they had breathed oxygen continuously for 3 days. Prolonged oxygen breathing also hastened the transfer of radioactive albumin from plasma into lymph, without affecting pulmonary arterial or left atrial pressures. These findings clearly reflect an oxygeninduced change in pulmonary microvascular permeability to protein. The $20 \%$ increase in [lymph total protein]/[plasma total protein] and the 28\% decrease in the [albumin]:[globulin] in lymph/[albumin]:[globulin] in plasma provide further evidence that oxygen altered the normal sieving properties of the pulmonary microvascular membrane, causing pulmonary edema despite a normal intravascular filtration pressure.

These results are virtually identical to results of previous experiments performed in our laboratory in which lambs breathed oxygen continuously but did not receive vitamin $E$ (4). We therefore conclude that vitamin $\mathrm{E}$ was not effective in protecting the lungs from oxygen toxicity.

Our results are different from those of McMillan and Boyd (22), who gave vitamin E $(13 \mathrm{mg} / \mathrm{kg}$ daily) and selenium $(0.3 \mathrm{mg} / \mathrm{kg}$ daily) to newborn lambs that breathed oxygen. They reported that lymph flow increased less in the treated lambs than it did in a group of untreated lambs that breathed pure oxygen. Their studies differed from ours in at least two ways: first, they gave two antioxidants; and second, they performed their experiments 1130 meters above sea level, so that the partial pressure of oxygen in the inspired gas was 610 torr or less. We cannot exclude the possibility that the combination of vitamin $E$ and selenium protects against the development of pulmonary oxygen toxicity. Lucy (21) suggested that much of the antioxidant activity of vitamin $E$ is mediated by selenium. It is also possible that antioxidants, such as vitamin $\mathrm{E}$ and selenium, are more effective when oxygen is delivered at a pressure of less than 1 atmosphere. Crapo and Tierney (6) have shown that administration of $85 \%$ oxygen to rats increases their production of superoxide dismutase, which defends against the action of free radicals and thereby inhibits lung injury during subsequent exposure to $100 \%$ oxygen.

Our results do not support the preliminary claim of Ehrenkranz and coworkers (12), who suggested that vitamin E might prevent the development of bronchopulmonary dysplasia, a condition that occurs in newborn infants who breathe oxygen-enriched gas for several days. Subsequent studies by Ehrenkranz et al. (11) and others $(14,32)$ have failed to show that vitamin $\mathrm{E}$ provides any benefit against oxygen-induced lung injury.

There are at least two possible explanations for the failure of vitamin $\mathrm{E}$, even at pharmacologic doses, to protect the lungs of lambs from oxygen toxicity. Vitamin E acts primarily as a lipid antioxidant, which prevents peroxidation of polyunsaturated fatty acids by scavenging free radicals generated during the univalent reduction of molecular oxygen $(2,10,20,28)$. The protective effect of vitamin E may be related either to the amount of vitamin E available to act as a scavenger or to the concentration of free 
Table 2. Vascular pressures, protein concentrations and lung lymph flow in six lambs breathing air, then $100 \% \mathrm{O}_{2}{ }^{1}$

\begin{tabular}{|c|c|c|c|c|c|c|c|c|}
\hline & \multirow{3}{*}{$\begin{array}{l}\text { Pulmonary } \\
\text { artery } \\
\text { pressure } \\
\text { (torr) }\end{array}$} & \multirow{3}{*}{$\begin{array}{c}\begin{array}{c}\text { Left } \\
\text { atrial }\end{array} \\
\text { pressure } \\
\text { (torr) }\end{array}$} & \multirow{3}{*}{$\begin{array}{l}\text { Lymph } \\
\text { flow } \\
\left(\mathrm{ml} \cdot \mathrm{h}^{-1}\right)^{2}\end{array}$} & \multicolumn{2}{|c|}{ Protein Concentrations } & \multirow{3}{*}{$\begin{array}{l}\text { Protein } \\
\text { clearance } \\
\left(\mathrm{ml} \cdot \mathrm{h}^{-1}\right)^{3}\end{array}$} & \multirow{3}{*}{$\begin{array}{c}\begin{array}{c}\text { Total protein } \\
\text { in lymph }\end{array} \\
\begin{array}{c}\text { Total protein } \\
\text { in plasma }\end{array}\end{array}$} & \multirow{3}{*}{$\begin{array}{c}\text { [Albumin]:[Globulin] } \\
\text { in lymph }\end{array}$} \\
\hline & & & & Lymph & Plasma & & & \\
\hline \multicolumn{3}{|c|}{$(g / d l)$} & & & & & & \\
\hline Baseline & $17 \pm 1$ & $3 \pm 1$ & $0.10 \pm 0.02$ & $2.73 \pm 0.36$ & $5.07 \pm 0.12$ & $0.052 \pm 0.008$ & $0.54 \pm 0.06$ & $2.05 \pm 0.25$ \\
\hline \multicolumn{9}{|l|}{ Hours in $\mathrm{O}_{2}$} \\
\hline $0-4$ & $15 \pm 1$ & $3 \pm 1$ & $0.10 \pm 0.02$ & $2.63 \pm 0.33$ & $5.02 \pm 0.12$ & $0.051 \pm 0.008$ & $0.52 \pm 0.06$ & $2.06 \pm 0.27$ \\
\hline $24-28$ & $16 \pm 1$ & $4 \pm 1$ & $0.07 \pm 0.01$ & $3.03 \pm 0.26$ & $5.20 \pm 0.12$ & $0.038 \pm 0.006$ & $0.58 \pm 0.04$ & $1.73 \pm 0.24$ \\
\hline $48-52$ & $17 \pm 2$ & $3 \pm 1$ & $0.09 \pm 0.02$ & $3.04 \pm 0.26$ & $5.24 \pm 0.09$ & $0.053 \pm 0.013$ & $0.58 \pm 0.04$ & $1.86 \pm 0.11$ \\
\hline $72-76$ & $14 \pm 2$ & $1 \pm 1$ & $0.30 \pm 0.06^{4}$ & $3.28 \pm 0.37^{4}$ & $5.20 \pm 0.17$ & $0.176 \pm 0.021^{4}$ & $0.63 \pm 0.07$ & $1.49 \pm 0.03^{4}$ \\
\hline $96-100$ & $19 \pm 4$ & $1 \pm 3$ & $0.25 \pm 0.04$ & $3.21 \pm 0.18$ & $5.36 \pm 0.19$ & $0.153 \pm 0.028$ & $0.60 \pm 0.05$ & $1.53 \pm 0.14$ \\
\hline
\end{tabular}

${ }^{1}$ Numbers are mean \pm S.E.

${ }^{2}$ Per $g$ of dry lung tissue.

${ }^{3}$ Per $\mathrm{g}$ of dry lung tissue, per $\mathrm{g}$ of plasma protein $\cdot \mathrm{dl}^{-1}$.

${ }^{4}$ Significant difference between measurements obtained during the first four hours in oxygen and those obtained between $72-76 \mathrm{~h}$ in oxygen.

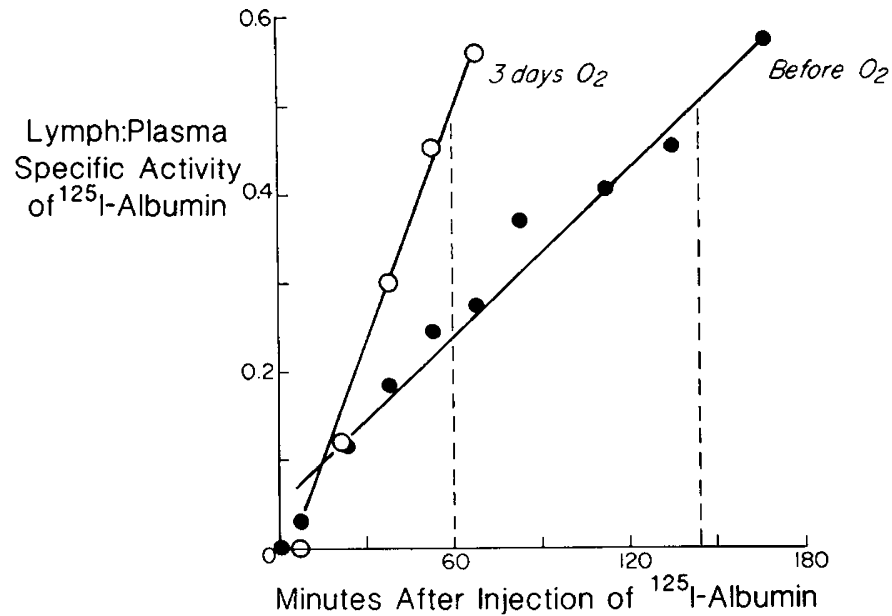

Fig. 2. Lymph:plasma specific activity of $\left[{ }^{125} \mathrm{I}\right]$-albumin as a function of time after intravascular injection of the radioactive tracer in one lamb. The time required for half-equilibration decreased from 144 min before oxygen breathing to 60 min after 3 days in oxygen.

radicals in the tissue. The dose of vitamin $E$ that we used was greater than that used by McMillan and Boyd (22) and identical to that used by Ehrenkranz and coworkers $(11,12)$. Our results do not allow us to predict whether or not larger doses of vitamin $E$ would be effective in protecting the lungs from oxygen toxicity. In a recent report, however, Yam and Roberts (34) showed that vitamin $\mathrm{E}$, administered to adult rats in a dose that was 10 times greater than the dose that our lambs received, did not prevent pulmonary oxygen toxicity.

Vitamin $\mathrm{E}$ also may function as a structural component of membranes, making the polyunsaturated fatty acids in the membranes more resistant to peroxidation (21). In all six of our experiments, the lambs received vitamin $E$ for 2 days before they began breathing oxygen, and then for the duration of oxygen exposure. This interval should have allowed sufficient time for vitamin $\mathrm{E}$ to become incorporated into the membranes. If this process requires more than 2 days, then vitamin $E$ in any dose is unlikely to be useful clinically in protecting newborn lungs from cxygen toxicity.

\section{REFERENCES AND NOTES}

1. Bland, R. D. and McMillan, D. D.: Lung fluid dynamics in awake newborn lambs. J. Clin. Invest., 60: 1107 (1977).

2. Boxer, L. A., Harris, R. E., and Baehner, R. L.: Regulation of membrane peroxidation in health and disease. Pediatrics, Suppl., 64: 713 (1979).

3. Boyd, M. R., Catignoni, G. L., Sasame, H. A., Mitchell, J. R., and Stiko, A. W.: Acute pulmonary injury in rats by nitrofurantoin and modification by vitamin $\mathrm{E}$, dietary fat, and oxygen. Am. Rev. Resp. Dis., 120: 93 (1979).
4. Bressack, M. A., McMillan, D. D., and Bland, R. D.: Pulmonary oxygen toxicity: Increased microvascular permeability to protein in unanesthetized lambs. Lymphology, 12: 133 (1979).

5. Clark, J. M. and Lambertson, C. J.: Pulmonary oxygen toxicity: a review. Pharmacol. Rev., 23: 37 (1971).

6. Crapo, J. D. and Tierney, D. F.: Superoxide dismutase and pulmonary oxygen toxicity. Am. J. Physiol., 226: 1401 (1974).

7. DeLemos, R., Wolfsdorf, J., Nachman, R., Block, A. J., Leiby, G., Wilkinson, H. A., Allen, T., Haller, J. A., Morgan, W., and Avery, M. E.: Lung injury from oxygen in lambs. Anesthesiology, 30: 609 (1969).

8. Demopoulos, H. B.: The basis of free radical pathology. Fed. Proc., 32: 1859 (1973).

9. Deneke, S. M. and Fanburg, B. L.: Normobaric oxygen toxicity of the lung. N. Engl. J. Med., 303: 76 (1980).

10. Ehrenkranz, R. A.: Vitamin E and the neonate. Am. J. Dis. Child., 134: 1157 (1980).

11. Ehrenkranz, R. A., Ablow, R. C., and Warshaw, J. B.: Prevention of bronchopulmonary dysplasia with vitamin $\mathrm{E}$ administration during the acute stages of respiratory distress syndrome. J. Pediatr. Suppl., 85: 873 (1979).

12. Ehrenkranz, R. A., Bonta, B. W., Ablow, R. C., and Warshaw, J. B.: Amelioration of bronchopulmonary dysplasia after vitamin $\mathrm{E}$ administration: a preliminary report. N. Engl. J. Med., 299: 564 (1978).

13. Erdmann, A. J., III, Vaughan, T. R., Jr., Brigham, K. L., Woolverton, W. C., and Staub, N. C.: Effect of increased vascular pressure on lung fluid balance in unanesthetized sheep. Circ. Res., 37: 271 (1975).

14. Finer, N. N., Peters, K. L., Schindler, R. F., and Grant, G. G.: Vitamin E, retrolental fibroplasia and bronchopulmonary dysplasia: controlled trial in the low birth weight neonate. Pediatr. Res., 15: 660 (1981).

15. Gilbert, D. L.: The role of pro-oxidants and antioxidants in oxygen toxicity. Radiat. Res. Supp., 3: 44 (1963).

16. Gornall, A. B., Bardawill, C. J., and David, M. M.: Determination of serum proteins by means of the Biuret reaction. J. Biol. Chem., 177: 751 (1949).

17. Haggard, N.: Cellular mechanisms of oxygen toxicity. Physiol. Rev., 48: 311 (1968).

18. Hansen, L. G. and Warwick, W. J.: A fluorometric micro method for serum tocopherol. Am. J. Clin. Pathol., 46: 133 (1966).

19. Johnson, K. J., Fantone, J. C., Kaplan, J., and Ward, P. A.: In vivo damage of rat lungs by oxygen metabolites. J. Clin. Invest., 67: 983 (1981).

20. Kann, H. E., Mengel, C. E., Smith, W., and Horton, B.: Oxygen toxicity and vitamin E. Aerospace Med., 35: 840 (1964).

21. Lucy, J. A.: Functional and structural aspects of biological membranes: a suggested structural role for vitamin $\mathrm{E}$ in the control of membrane permeability and stability. Ann. N.Y. Acad. Sci., 203: 4 (1972).

22. McMillan, D. D. and Boyd, G. N.: Modification of oxygen-induced increased pulmonary microvascular permeability in 1-2 week old lambs given vitamin $\mathrm{E}$ and selenium. Am. Rev. Resp. Dis., 121: 296 (1980).

23. Pearce, M. L., Yamashita, J., and Beazell, J.: Measurement of pulmonary edema. Circ. Res., 16: 482 (1965).

24. Poland, R. L., Bollinger, R. O., Bozynski, M. E., Karna, P., and Perrin, E. V. D.: Effect of vitamin E deficiency on pulmonary oxygen toxicity. Pediatr. Res., 11 : 577 (1977).

25. Rudolph, A. M.: Congenital Diseases of the Heart, p. 139-145 (Year Book, Chicago, IL, 1974).

26. Snedecor, G. W. and Cochran, W. G.: Statistical Methods, Ed. 6, p. 91-119 (lowa State University Press, Ames, Iowa, 1972).

27. Staub, N. C., Bland, R. D., Brigham, K. L., Demling, A. J., Erdmann, W. C., and Woolverton, W. C.: Preparation of chronic lung lymph fistulas in sheep. J. Surg. Res., 19: 315 (1975).

28. Tappel, A. L.: Vitamin $E$ and free radical peroxidation of lipids. Ann. N.Y. Acad. Sci., 203: 13 (1972).

29. Tappel, A. L.: Lipid peroxidation damage to cell components. Fed. Proc., 32: 1870 (1973). 
30. Taylor, D. W.: The effects of vitamin E deficiency on oxygen toxicity in the rat. J. Physiol. (Lond), 121: 47p (1953)

31. Taylor, D. W.: The effects of vitamin $E$ and methylene blue on the manifestations of oxygen poisoning on the rat. J. Physiol. (Lond), 131: 200 (1956).

32. Watts, J. L., Pocs, B. A., Milner, R. A., Zipursky, A., Gill, G. J., and Fletcher, B. A.: Randomized controlled trial of vitamin $\mathrm{E}$ and bronchopulmonary dysplasia. Pediatr. Res., 15: 686 (1981).

33. Wender, D. F., Thulin, G. E., Walker-Smith, G. J., and Warshaw, J. B.: Vitamin $\mathrm{E}$ affects lung biochemical and morphologic response to hyperoxia in the newborn rabbit. Pediatr. Res., 15: 262 (1981).

34. Yam, J., and Roberts, R. J.: Pharmacologic alterations of oxygen-induced lung toxicity. Toxic. and Appl. Pharm., 47: 367 (1979).

35. The authors thank R. Goldberg and T. M. Chou for technical assistance and

Copyright (C) 1982 International Pediatric Research Foundation, Inc. $0031-3998 / 82 / 1607-0583 \$ 0.200 / 0$
Mrs. M. Biagini for typing the manuscript.

36. Requests for reprints should be addressed to: Dr. Richard D. Bland, Cardiovascular Research Institute, University of California, San Francisco, CA 94143.

37. This research was supported in part by National Heart, Lung and Blood Institute (NHLBI) Pulmonary Specialized Center of Research (SCOR) Grant HL 19185 and by U.S. Public Health Service Program Project Grant HL 25816. Dr. Hansen and Dr. Hazinski were Academic Pulmonary Faculty Trainees from Baylor College of Medicine, Houston, TX, and Northwestern University School of Medicine, Chicago, IL, respectively. They were supported by NHLBI Pulmonary Faculty Training Grant HL 07159. Dr. Bland did this work during his tenure as an Established Investigator of the American Heart Association. 38. Received for publication August 6, 1981.

39. Accepted for publication December 4, 1981. 